writers a place to develop and test ideas that they might later incorporate into a lengthier post, and directing readers to the detailed content they want. "Discovery of science blogs is increasingly through social media," she says.

\title{
RISKS AND BENEFITS
}

Blogging does have potential pitfalls. For a start, it is not likely to make anyone wealthy. "It's probably not worth doing it for the money unless your audience is huge," says McGlynn. Small Pond Science, which has had more than 570,000 visits in total, doesn't take ads. But even if it did, McGlynn has calculated, he'd probably clear only US $\$ 10,000$ to $\$ 20,000$ a year.

Academic colleagues might think that blogging is a waste of time or damaging to a career. "Some people say blogging and social media are distractions and will hurt you on the job market because it demonstrates that you're not serious," McGlynn says. When Robinson-Rechavi started blogging in 2010 ,

he signed his posts using only his initials, unsure how people would react - even though he already had tenure and faced little risk. He thinks that his col-

"The ultimate goal is to level the playing field for people who aren't aware that there is even a game at play."

leagues don't understand why he blogs and are indifferent to his posts. Yet administrators at his university consider his blogging a useful forum for communicating ideas. "I think they like that I'm doing it," he adds.

It's worth considering the inherent risk in putting one's name, face and ideas on the Internet. McDonald says that bloggers and particularly women - need to think carefully before they post, because online visibility can expose writers to abuse.

Still, McDonald keeps at it, happy to be involved in broader conversations about teaching, biology, women in academia - and Star Trek. When she came up for tenure, she discussed her blog in her application. "This is part of my outreach and advocacy work for diversity in science," she says. Blogging helps her to take her research into the world, a goal that she believes is crucial for scientists.

"We hear all the time about the decline of blogging," Heard says. But he has no intention of quitting and will continue to spread the word about its benefits. "I hope that those who are on the fence - those who think it might be for them - can be encouraged to give it a go." -

Eryn Brown is a writer and editor in Los Angeles, California. Chris Woolston is a freelance writer in Billings, Montana.

COLUMN

Make yourself heard

\section{Researchers who want to 'do something about it' can join with others to effect change, says Sarah Hamylton.}

$\mathrm{T}$

The impacts of climate change are real. Plant and animal habitats are changing, glaciers are melting and heatwaves and floods are becoming more frequent. All this causes me to question the utility of my work as an environmental scientist.

Reports that two mass coral-bleaching episodes in 2016 and 2017 had killed around half the coral on the Great Barrier Reef stopped me short. Having spent the past decade modelling the impacts of climate change on coral reefs, I feel as if much of that work is now futile.

Environmental scientists are calling attention to changes in the natural world that are driven by carbon emissions from burning fossil fuels. In doing so, we speak of the 'grief' of climate science, using words such as 'demoralizing', 'conflicted' and 'deep sense of worry'. Charlie Veron, a world authority on coral and former chief scientist of the Australian Institute of Marine Science, told the Australian Broadcasting Corporation's Radio National in 2016: "I am someone who can actually do something about it. I am someone who is listened to and I have made a difference. And so I have to keep on doing that. It's not as if I can say, 'to hell with it', and go and do some gardening."

We have a responsibility to lead change. This responsibility raises questions, such as: how do scientists cope with the emotional burden of their knowledge? And how can these emotions galvanize us into action?

In 2017, I joined Homeward Bound, a global environmental-leadership programme for women in science that launched in 2016. Each year, the programme coaches up to 150 women for 12 months, culminating in a 3 -week voyage to Antarctica, where female scientists develop their confidence and strategic vision for acting together on climate change. The programme has focused my attention on projecting my voice as an environmental scientist.

In 2015, I became a councillor of the Australian Coral Reef Society (ACRS), the world's oldest society for protecting Australia's coral reefs, which has a track record of calling for change. That year, we wrote submissions and reports on behalf of more than 300 concerned scientists in what became known as the 'coal versus coral' war. The Great Barrier Reef Marine Park Authority had approved a proposal to dump 3 million cubic metres of dredged sediment from Abbot Point, a huge coal port in northern Queensland, into the

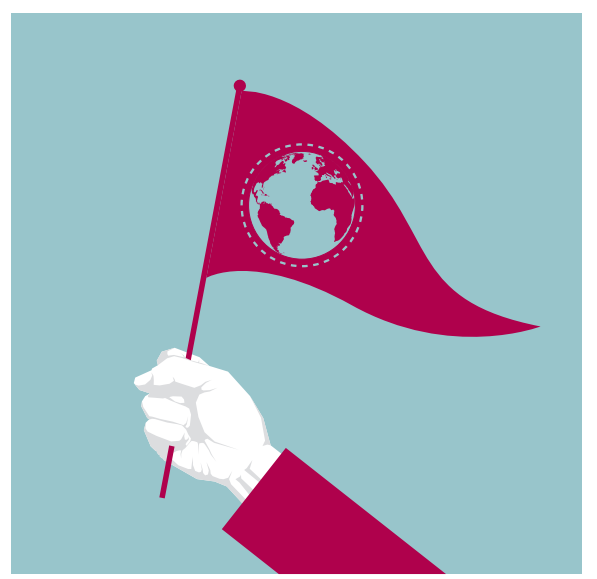

Great Barrier Reef World Heritage Area.

This would have been an environmental disaster, with plumes of sediment compromising marine life. The authority reversed its decision when the ACRS made its views known alongside those of conservationists, tourism operators, grassroots organizations such as GetUp! and the indigenous climate group Seed. It was immensely satisfying to be part of this endeavour. To keep up the pressure, we sent a letter last August on behalf of the ACRS to Australia's prime minister, Malcolm Turnbull, urging immediate action to curb carbon emissions.

I have also begun to explore how interdisciplinary approaches weave together different practices to create powerful ways of communicating the science of climate change. Last September, I became an unlikely 'artist in residence' at the Bundanon Trust in Illaroo, Australia, which supports creative work that emphasizes the value of landscapes. I am working with artists and a social scientist to untangle how interdisciplinary approaches saved the Great Barrier Reef from mining in the 1960s - and whether such approaches can help scientists to save it again.

Emotional conflicts around climate change have prompted me to revisit the reasons I became an environmental scientist. I am now using forms of expression that resonate with my personal values and add scientific authority to the argument for resisting the coal industry. How will you lead the change you want to see?

Sarah Hamylton is a senior lecturer in geographic information sciences at the University of Wollongong, Australia. 